\title{
Followership Characteristics among US Federal Government Employees*
}

\author{
Chulwoo Kim**
}

\begin{abstract}
Empowering collective action among leaders and followers in the US public sector has been encouraged to solve public problems in a complex and globalized society. However, without considering who the participants are, how much influence they have, and the various situations in which they find themselves, empowerment is not an adequate solution to existing public challenges. Understanding followership — the process empowered participants use to followis a prerequisite to understanding successful empowerment. This study examines followership as it is practiced within the US federal government. Data from the Federal Human Capital Survey data, which had 212,223 respondents and was administered by the Office of Personnel Management in 2008, were used. The results indicate that different followership styles are dominant in different agencies. Followership styles also differ depending on job rank, which also explains possible distinctions between different groups in public organizations.
\end{abstract}

Keywords: followership, leadership, US federal government

\section{INTRODUCTION}

The existing literature indicates that when problems and solutions are clear, leaders can facilitate solutions independently, but when solutions are unclear in an organization or society with complex, intractable problems, leaders help groups to solve problems (Greiner, 1972; Heifetz, 1994; Chrislip, 2002; Vigoda, 2002). Empowering subordinates is a prerequisite for collective problem-solving. However, without carefully considering who the empowered participants are (beside leaders) and what attitudes

* This paper was part of a $\mathrm{PhD}$ dissertation written by the author.

** Chulwoo Kim has a PhD in public administration from the School of Public Affairs and Administration at Rutgers University. His research interests include organizational behavior, leadership, human resource management, citizen participation, and performance management. E-mail: czaroo@rutgers.edu.

Manuscript received June 8, 2011; out for review June 16, 2011; review completed July 13, 2011; accepted August 1, 2011.

The Korean Journal of Policy Studies, Vol. 26, No. 2 (2011), pp. 101-120.

(C) 2011 by the GSPA, Seoul National University 
and behaviors they have, collective problem-solving is not a solid solution to complex public challenges.

This study reviews key models of followership_defined as the process empowered participants use to follow-and analyzes the differences in followership between and within US federal agencies by applying Kelley's (1992) followership model. First, the findings of followership by agency, sub-agency, and location are reported. These findings represent horizontal views on followership. Second, followership within federal agencies is described based on vertical categories such as rank, pay grade, age group, federal tenure, and agency tenure. After analysis, the findings are discussed.

\section{LITERATURE REVIEW}

\section{Definition of Followership}

Kellerman (2007) defined followers based on their rank; they are low in the hierarchy and have less power, authority, and influence than their superiors. But she added the following:

History tells us, however, that subordinates do not follow all the time. Followers think of themselves as free agents, not as dependent underlings. And they act accordingly, often withholding support from bad leaders, throwing their weight behind good ones, and sometimes claiming commanding voice for those lower down in the social or organizational hierarchy. (Kellerman, 2007)

Kellerman's comments on subordinates are well supported by previous literature on followership. Kelley (1992) said followers are people who act with intelligence, independence, courage, and a strong sense of ethics. Chaleff (1995) and Dixon (2003) shared the opinion that followers are not the same as subordinates. By their definitions, followers are those who understand and try to accomplish the purpose and vision of their leaders and organizations. Rost (2008) defined followership as the process people use to follow. Followership is what people do when they interact in an organization with leaders to accomplish something.

\section{Characteristics of Effective Followership}

Kelley (1988) concluded that effective followers are well-balanced and responsible adults who can succeed without strong leadership. Since followership is not a person but a role, he said, effective followers and effective leaders are the same people who 
just take different roles at different time in their workplace. He suggested (p. 144) four qualities of effective followers: (1) self-management, (2) commitment (to the organization and to a purpose, principle, or person outside themselves), (3) competence and focus, and (4) courage (a quality that includes honesty and credibility).

Chaleff (2008, p. 41) described followers with high support and high challenge as being purpose-driven and mission-oriented. They are risk takers who cultivate relationships, hold themselves and others accountable, confront sensitive issues, focus on strengths and growth, have peer relations with authority, and complement the leader's perspectives.

Goffee and Jones (2006) introduced three characteristics of good followers: (1) they are prepared to speak up in spite of personal risk, (2) they are prepared to complement the leader, and (3) they have a skillful appreciation of change and timing. Good followers, according to Kellerman (2007), invest their efforts to make appropriate judgments and actions which support good (effective and ethical) leaders and oppose bad (ineffective and unethical) leaders. Effective followers are also enthusiastic and self-reliant participators in terms of accomplishing organizational goals (Bjugstad, Thach, Thompson, \& Morris, 2006). In sum, the role of the effective follower is to implement decisions made by a leader and to challenge decisions that are misguided or unethical (Yukl, 2009).

Table 1. Theories of Followership

\begin{tabular}{l|l|l|l}
\hline Study & Definitions & Dimensions & Models \\
$\begin{array}{l}\text { Zaleznik } \\
(1965)\end{array}$ & $\begin{array}{l}\text { Does not provide the definition but } \\
\text { focused on the negative side of the } \\
\text { followers }\end{array}$ & $\begin{array}{l}\text { Dominance/submission } \\
\text { Activity/passivity }\end{array}$ & $\begin{array}{l}\text { Impulsive } \\
\text { Compulsive } \\
\text { Masochistic } \\
\text { Withdrawn }\end{array}$ \\
\hline $\begin{array}{l}\text { Kelley } \\
\text { (1992) }\end{array}$ & $\begin{array}{l}\text { People who act with intelligence, } \\
\text { independence, courage, and a strong } \\
\text { sense of ethics }\end{array}$ & $\begin{array}{l}\text { Independent, critical thinking } \\
\text { Dependent, uncritical thinking } \\
\text { Active/passive engagement }\end{array}$ & $\begin{array}{l}\text { Alienated } \\
\text { Conformist } \\
\text { Pragmatist } \\
\text { Passive }\end{array}$ \\
\hline $\begin{array}{l}\text { Chaleff } \\
\text { (1995) }\end{array}$ & $\begin{array}{l}\text { People who understand and try to } \\
\text { accomplish the purpose and vision of } \\
\text { their leaders and organizations }\end{array}$ & $\begin{array}{l}\text { High/low support } \\
\text { High/low challenge }\end{array}$ & $\begin{array}{l}\text { Partner } \\
\text { Individualist } \\
\text { Implementer }\end{array}$ \\
\hline & $\begin{array}{l}\text { Reople who are low in the hierarchy } \\
\text { and have less power, authority, } \\
\text { and influence than their superiors } \\
\text { (2007) }\end{array}$ & Level of engagement \\
\hline
\end{tabular}




\section{Models of Followership}

Based on effective follower characteristics, several followership models have been developed. One of the earliest follower typologies was introduced by Zaleznik in "The Dynamics of Subordinacy" (1965), which highlighted the importance of the relationship between leaders and followers and its impact on organizational performance. The two dimensions Zaleznik uses to distinguish subordinates are dominance (controlling) vs. submission (being controlled), and activity vs. passivity (willingness or unwillingness to participate).

Kelley's (1992) model offers five categories of followers: alienated, conformist, pragmatist, passive, and exemplary. The two dimensions he used to categorize these five groups are whether followers are critical thinkers (creative and innovative) and engage actively (taking initiative in decision making). Figure 1 illustrates these styles.

Figure 1. Followership Styles according to Kelley

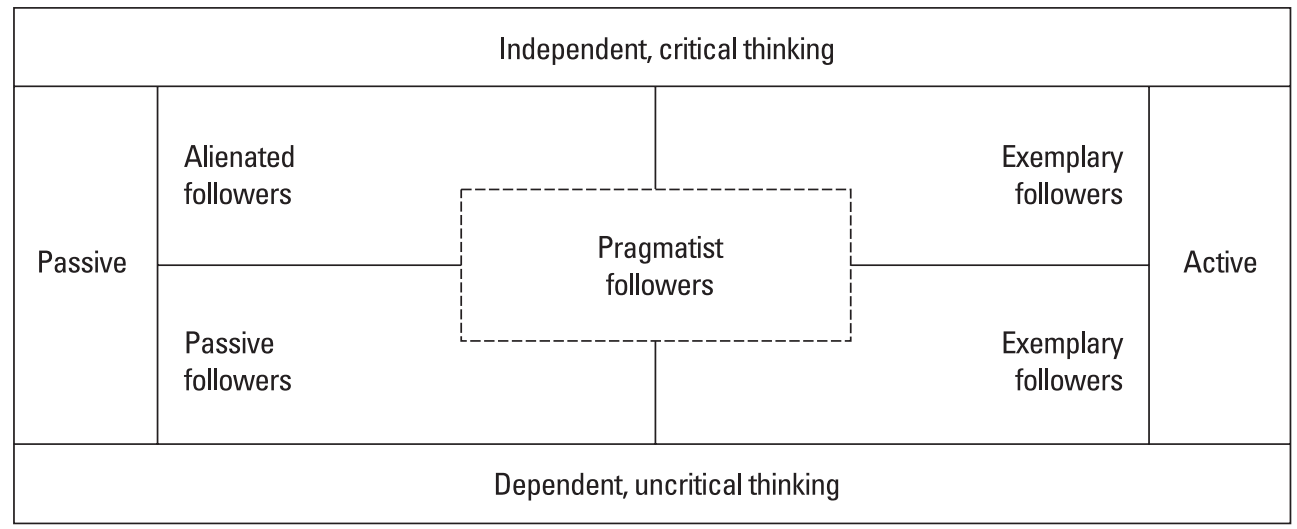

Source: Kelley, 1992.

Kelley (1992) added that followership style is not fixed but can change depending on the situation. Therefore, it is better to understand a style as dominant rather than exclusive for a given person. The following is a summary of the behavioral characteristics of Kelley's five follower types:

- Passive followers (sheep) look to the leader to do the thinking for them and to motivate them.

- Conformist followers (yes people) are positive, always on the leader's side, but still looking to the leader for thinking, direction, and vision.

- Alienated followers (mavericks) have energy; they can think for themselves. However, they are negative, skeptical, and cynical about the current plan of 
action.

- Pragmatists, so-called preservers of the status quo, never start something, but when things are decided and planned, they follow.

- Exemplary followers can think for themselves; they are active and have positive energy. They do not simply agree with leaders without their own independent evaluation. They give full support when they agree. But when they disagree, they challenge leaders and suggest constructive alternatives that may help the leader and the organization.

Townsend (1999) categorized followers as either passive or active. Subordinates with a passive followership style follow leaders without questioning, while active followership means a more interactive relationship with leaders.

Chaleff (1995) commented that what separates one follower from another is how much courage he or she has. In this context, courageous followers are the ones who can give their leaders constructive criticism and suggestions when leaders are not making the right decisions for their organizations. The two dimensions he suggested are degree of support and degree of willingness to challenge leaders (Chaleff, 2008). These two dimensions provide four different types of followership: partner, implementer, individualist, and resource.

Figure 2. Followership Styles according to Chaleff

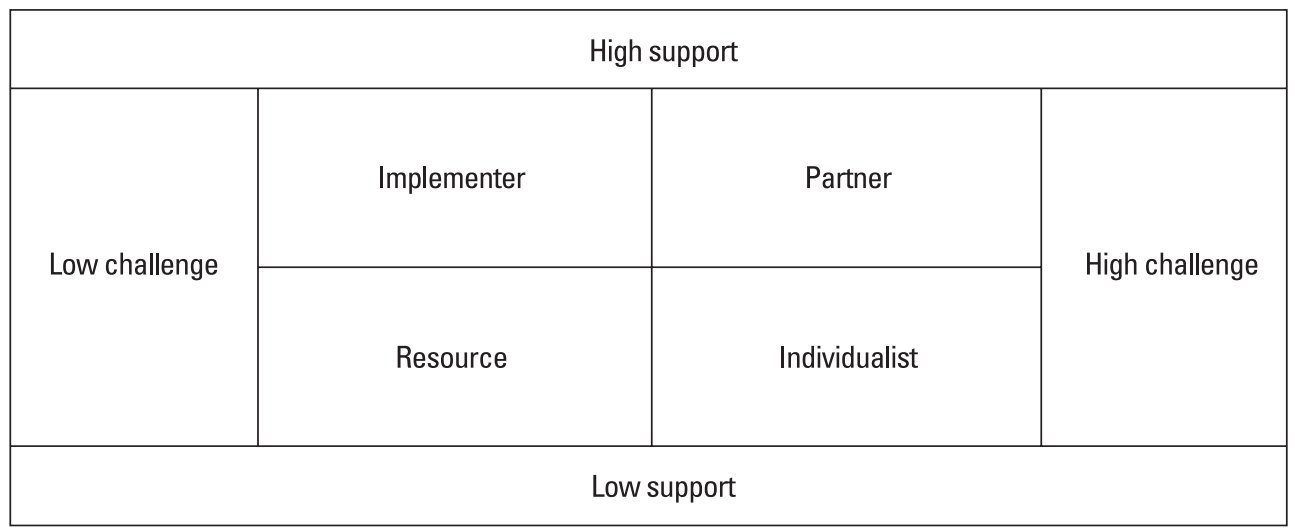

Source: Chaleff, 2008

Unlike earlier theorists, Kellerman (2007) used one criterion in categorizing followers: level of engagement, she argued, for the most part determines the nature of superior-subordinate relationships. Using this criterion, she divided followers into five categories; isolates, bystanders, participants, activists, and diehards: 
Isolates are completely detached. They do not care about their leaders, know anything about them, or respond to them in any way. Bystanders observe but do not participate. They remain neutral about their leaders or groups and give implicit support that maintains the status quo. Participants are engaged in some way. They show their support or opposition by investing some of what they have (for example, time and money) to make an impact. Activists feel strongly about their leaders and act accordingly. They are eager, energetic, and engaged, and work hard in both positive and negative ways. Diehards are prepared to "die" if necessary for their cause. They are either deeply devoted to or totally opposed to their leaders. (Kellerman, 2007, pp. 86-92)

Among the various models of followership reviewed here, Kelley's model (1992), using the two dimensions of independent thinking and active engagement, is the most comprehensive, as it can embrace other models' dimensions and categorizations. Models by Gilbert and Hyde (1988), Chaleff (1995), Kellerman (2007), and Carsten et al. (2010) share perspectives very similar to Kelley's.

\section{METHODOLOGY}

\section{Data Sample}

This study analyzes data from the 2008 Federal Human Capital Survey (US OPM, 2008), which was administered by the Office of Personnel Management in 2008 to employees from major federal agencies represented on the President's Management Council and 54 smaller or independent agencies. The survey objective was to identify federal employees' perception of the degree of workforce management effectiveness. A random sample of 417,128 employees were selected to respond to the survey; 212,223 completed the survey (a response rate of 51 percent). The format of the survey was self-administered and online, but paper copies were available if needed (US OPM, 2008). Among 212,223 participants, 48.0 percent were female, 44.3 percent had a leadership position (team leader, supervisor, manager, or executive), and 72 percent were white.

\section{Measurement}

Followership is measured at the individual level. In this study, followership is considered to be the combined effect of multiple individuals' perceptions of their relationships with co-workers, and informal emergent structures or systems, such as goals, 
in organizations that reflect the combined effects of local interactions (Marion \& Uhl-Bien, 2001; Lord, 2008). Kelley's two criteria (independent critical thinking and active engagement), which have been used in previous followership studies, are applied to measure followership. The operational definition of independent thinking is "the willingness to provide constructive feedback, as well as the amount of creativity and innovativeness one brings to a job," and active engagement is defined as "intensity of participation and the amount of effort an individual is willing to commit in one's role" (Tanoff \& Barlow, 2002, p. 159).

Followership is measured based on six questions in the Federal Human Capital Survey. Kelley's (1992) criteria, active engagement and independent critical thinking, are measured based on three questions each. The questions were selected according to their consistency with variables used in the research cited above. The questions measuring independent critical thinking include 1) My work gives me a feeling of personal accomplishment, 2) I feel encouraged to come up with new and better ways of doing things, 3) I can disclose a suspected violation of any law, rule or regulation without fear of reprisal. Questions measuring active engagement consist of 1) The people I work with cooperate to get the job done, 2) I know how my work relates to the agency's goals and priorities, 3) I am held accountable for achieving results (asking whether employees are engaged and focused on achieving the results expected of them). Questions used a five-point Likert scale that ranged from "strongly disagree" (1) to "strongly agree" (5).

The mean of the results of three questions was derived. Then, the weighted scores were multiplied by the means. The data weighting helped to accurately represent the survey population by considering "the variable probabilities of selection across the sample domains, nonresponse, and known demographic characteristics of the survey population" (US OPM, 2008, p. 37).

\section{RESULTS}

Several mean tests including independent samples t-test, paired t-test, and one-way analysis of variance were conducted to see whether the variations in mean scores of followership are statistically significant. The result confirmed the means of the two dimensions of followership are statistically significantly different $(P=0.000)$. The mean score of followership also differs significantly among the different agencies and sub-agencies as well as different groups within agencies $(\mathrm{P}=0.000)$. 


\section{Horizontal Representation: Followership in Federal Agencies}

\section{Followership by Agency}

Figure 3 shows the overall followership measures of 76 federal agencies, including 15 executive departments and selected independent agencies. It indicates that agencies with higher mean scores in independent thinking have higher mean scores in active engagement.

Figure 3. Followership in Federal Agencies (Agency Level)

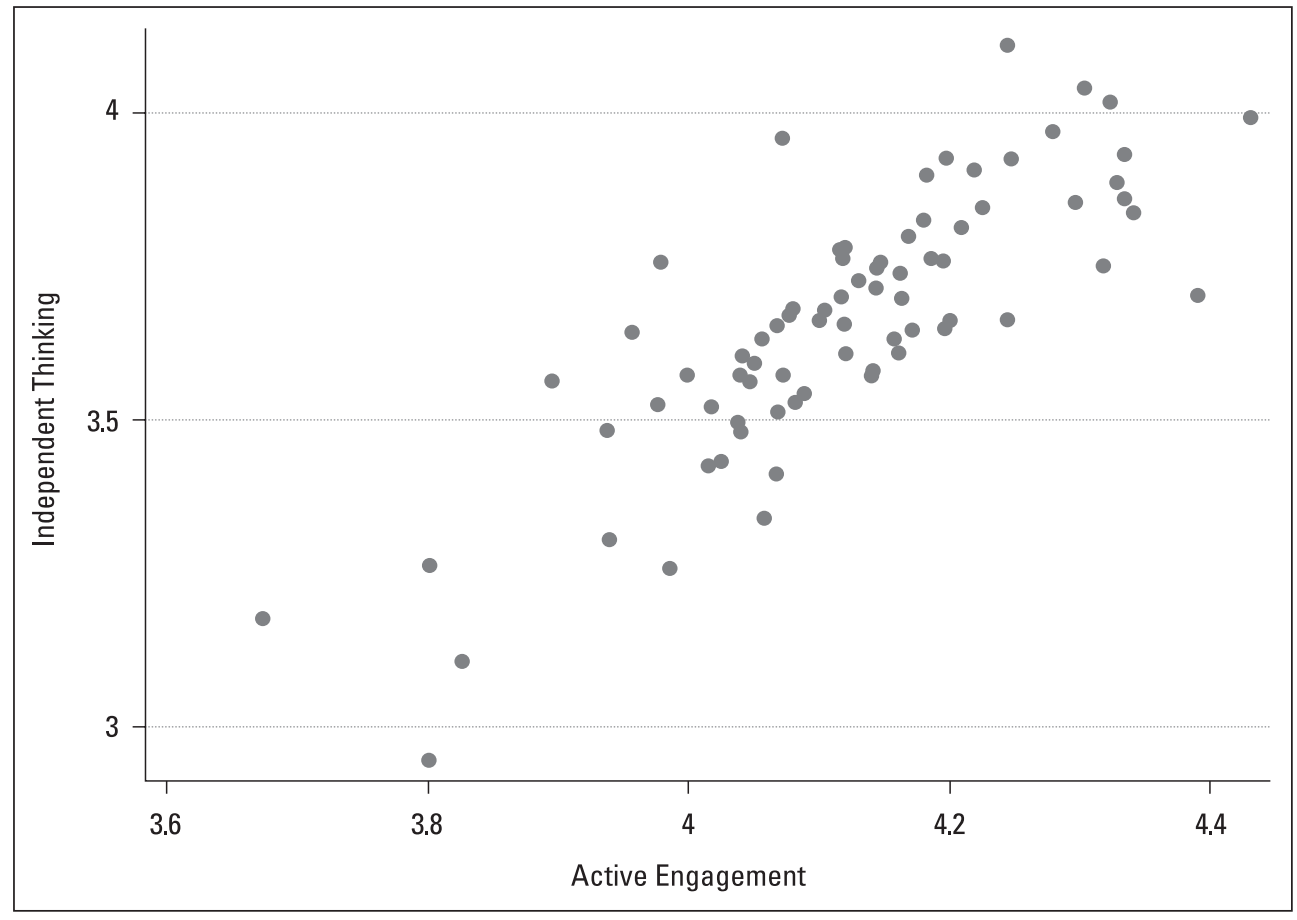

Among federal departments (see table 2), the Department of State has the highest independent thinking mean score (3.81) and the Department of Transportation the lowest (3.37). The Department of the Army is ranked second highest (3.71) and the Department of Homeland Security is second lowest (3.39) in independent thinking. In terms of active engagement, the Department of State again has the highest mean score (4.11) and the Department of Transportation the lowest (3.90). The Department of Commerce is second highest (4.10) and the Department of Homeland Security second lowest (3.94) among the federal departments. Overall, followership in federal departments seems to be lower than followership in independent agencies. 
Table 2. Followership by Federal Department

\begin{tabular}{l|c|c}
\hline Agency & Independent thinking & Active engagement \\
\hline Department of Agriculture & 3.56 & 3.995 \\
\hline Department of Commerce & 3.67 & 4.10 \\
\hline Department of Defense & & \\
\hline Department of the Air Force & 3.65 & 4.04 \\
\hline Department of the Army & 3.71 & 4.06 \\
\hline Department of the Navy & 3.68 & 4.05 \\
\hline Department of Justice & 3.63 & 4.03 \\
\hline Department of Labor & 3.55 & 4.09 \\
\hline Department of Energy & 3.63 & 4.06 \\
\hline Department of Education & 3.49 & 4.06 \\
\hline Department of Health and Human Services & 3.61 & 4.04 \\
\hline Department of Homeland Security & 3.39 & 3.93 \\
\hline Department of Housing and Urban Development & 3.42 & 4.02 \\
\hline Department of the Interior & 3.57 & 3.989 \\
\hline Department of State & 3.81 & 4.11 \\
\hline Department of Transportation & 3.37 & 3.90 \\
\hline Department of the Treasury & 3.58 & 4.05 \\
\hline Department of Veterans Affairs & 3.63 & 4.02 \\
\hline
\end{tabular}

Table 3 shows the federal agencies with the top and bottom 10 followership measures. Not surprisingly, science-related agencies (National Science Foundation and National Aeronautics and Space Administration) rank relatively high in independent thinking. The Office of Management and Budget has the highest mean (4.12) in independent thinking, while the Federal Labor Relations Authority has the lowest (2.94). The Postal Regulatory Commission ranks the highest (4.44) in active engagement and the Inter-American Foundation lowest (3.66).

It is interesting that none of the 15 federal departments are in the top-10 list in both measurements at the agency level. 
Table 3. Followership in Federal Agencies (Agency Level)

\begin{tabular}{|c|c|}
\hline \multicolumn{2}{|c|}{ Independent thinking } \\
\hline Top 10 agencies & Mean score \\
\hline $\begin{array}{l}\text { Office of Management and Budget } \\
\text { Nuclear Regulatory Commission } \\
\text { Postal Regulatory Commission } \\
\text { Defense Nuclear Facilities Safety Board } \\
\text { Federal Maritime Commission } \\
\text { National Science Foundation } \\
\text { National Aeronautics and Space Administration } \\
\text { Chemical Safety and Hazard Investigation Board } \\
\text { Office of the US Trade Representative } \\
\text { Trade and Development Agency }\end{array}$ & $\begin{array}{l}4.12 \\
4.02 \\
4.01 \\
3.96 \\
3.95 \\
3.93 \\
3.92 \\
3.91 \\
3.91 \\
3.87 \\
\end{array}$ \\
\hline Bottom 10 agencies & Mean score \\
\hline $\begin{array}{l}\text { National Labor Relations Board } \\
\text { Department of Homeland Security } \\
\text { Department of Transportation } \\
\text { Selective Service System } \\
\text { Federal Communications Commission } \\
\text { International Boundary and Water Commission } \\
\text { Broadcasting Board of Governors } \\
\text { Inter-American Foundation } \\
\text { Commission on Civil Rights } \\
\text { Federal Labor Relations Authority }\end{array}$ & $\begin{array}{l}3.40 \\
3.39 \\
3.37 \\
3.32 \\
3.31 \\
3.26 \\
3.23 \\
3.11 \\
3.11 \\
2.94 \\
\end{array}$ \\
\hline \multicolumn{2}{|c|}{ Active engagement } \\
\hline Top 10 agencies & Mean score \\
\hline $\begin{array}{l}\text { Postal Regulatory Commission } \\
\text { Merit Systems Protection Board } \\
\text { National Endowment for the Arts } \\
\text { Surface Transportation Board } \\
\text { Federal Retirement Thrift Investment Board } \\
\text { Nuclear Regulatory Commission } \\
\text { Office of the US Trade Representative } \\
\text { Trade and Development Agency } \\
\text { National Capital Planning Commission } \\
\text { Federal Maritime Commission }\end{array}$ & $\begin{array}{l}4.43 \\
4.38 \\
4.33 \\
4.32 \\
4.32 \\
4.32 \\
4.32 \\
4.30 \\
4.29 \\
4.27 \\
\end{array}$ \\
\hline Bottom 10 agencies & Mean score \\
\hline $\begin{array}{l}\text { Advisory Council on Historic Preservation } \\
\text { Federal Communications Commission } \\
\text { Office of Federal Housing Enterprise Oversight } \\
\text { Department of Homeland Security } \\
\text { Department of Transportation } \\
\text { Committee for Purchase from People Who Are Blind } \\
\text { Commission on Civil Rights } \\
\text { Federal Labor Relations Authority } \\
\text { Broadcasting Board of Governors } \\
\text { Inter-American Foundation }\end{array}$ & $\begin{array}{l}3.96 \\
3.94 \\
3.94 \\
3.93 \\
3.90 \\
3.90 \\
3.83 \\
3.80 \\
3.78 \\
3.66\end{array}$ \\
\hline
\end{tabular}




\section{Followership by Sub-agency}

Figure 4 and table 4 show followership measurements at the sub-agency level. The characteristic is similar to the one at the agency level. The Environment and Natural Resources Division under the Department of Justice has the highest mean score (4.13) in independent thinking, while the National Drug Intelligence Center, also under the Department of Justice, has the lowest (3.19). It is interesting that two sub-agencies within the same agency have the highest and lowest scores in independent thinking. The Office of Postsecondary Education is second lowest (3.20), and the Office of Management and Budget is second highest (4.12) in independent thinking. Regarding active engagement, the Environment and Natural Resources Division in the Department of Justice again has the highest mean score (4.39), followed by the Lyndon B. Johnson Space Center (4.32). The United States Mint in the Department of the Treasury has the lowest mean score (3.75), and the Bureau of Prisons/Federal Prison System, in the Department of Justice, has the second lowest mean score (3.85).

Figure 4. Followership in Federal Agencies (Sub-agency Level)

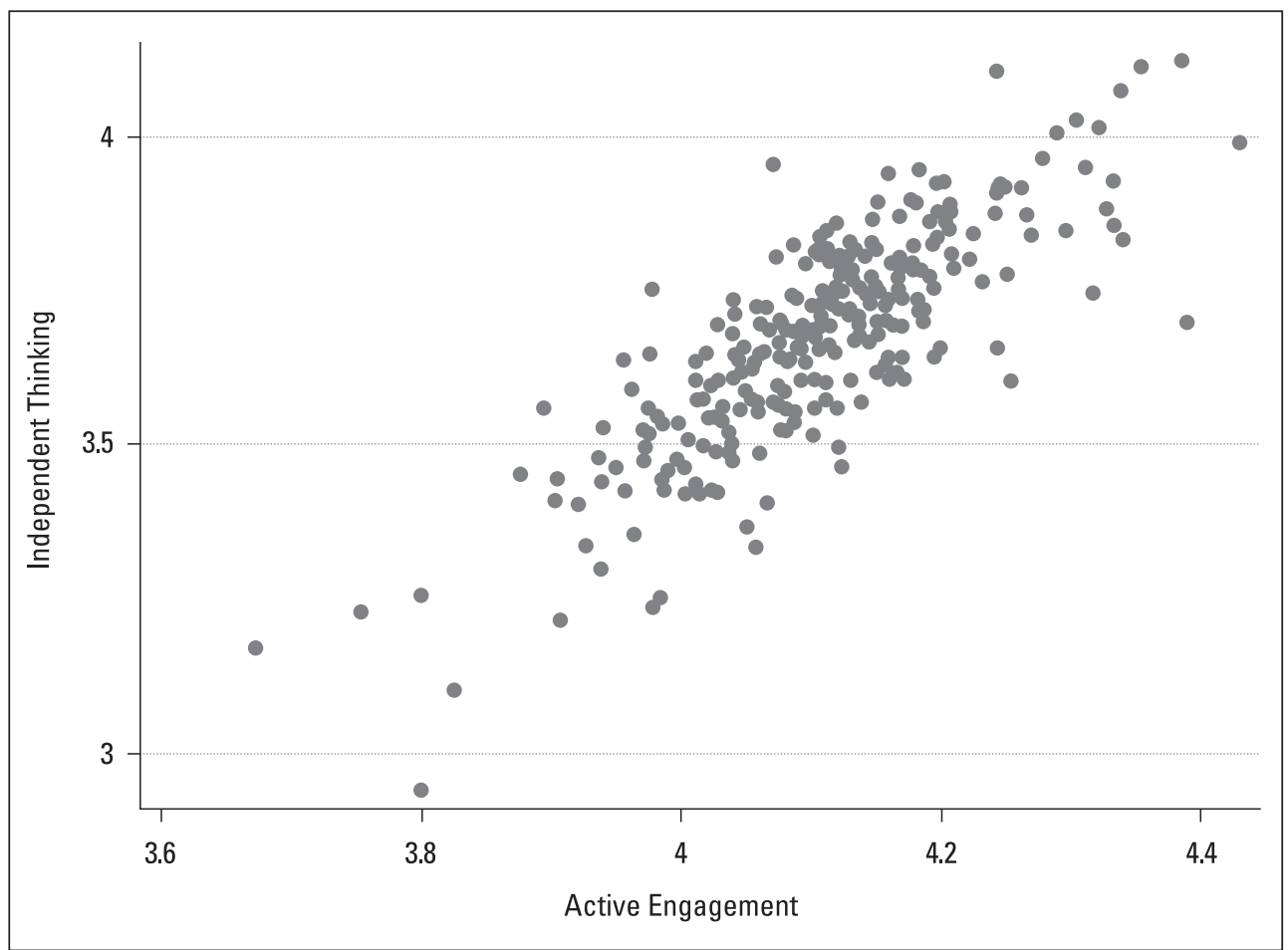


Table 4. Followership in Federal Agencies (Sub-agency Level)

\begin{tabular}{|c|c|}
\hline \multicolumn{2}{|l|}{ Independent thinking } \\
\hline Top 10 sub-agencies & Mean score \\
\hline $\begin{array}{l}\text { Environment and Natural Resources Division } \\
\text { Lyndon B. Johnson Space Center } \\
\text { Civil Division, Department of Justice } \\
\text { Goddard Space Flight Center } \\
\text { George C. Marshall Space Flight Center } \\
\text { Executive Office US Attorneys and US Attorneys' Office } \\
\text { Tax Division, Department of Justice } \\
\text { John C. Stennis Space Center } \\
\text { Criminal Division, Department of Justice } \\
\text { Alcohol and Tobacco Tax and Trade }\end{array}$ & $\begin{array}{l}4.13 \\
4.05 \\
4.01 \\
4.01 \\
3.98 \\
3.94 \\
3.93 \\
3.92 \\
3.92 \\
3.91\end{array}$ \\
\hline Bottom 10 sub-agencies & Mean score \\
\hline $\begin{array}{l}\text { Transportation Security Administration } \\
\text { Bureau of Prisons/Federal Prison System } \\
\text { Customs and Border Protection } \\
\text { Office for Civil Rights } \\
\text { Bureau of Engraving and Printing } \\
\text { Federal Aviation Administration } \\
\text { Transportation Security Administration } \\
\text { US Mint } \\
\text { Office of Postsecondary Education } \\
\text { National Drug Intelligence Center }\end{array}$ & $\begin{array}{l}3.41 \\
3.40 \\
3.38 \\
3.34 \\
3.32 \\
3.31 \\
3.25 \\
3.23 \\
3.20 \\
3.19\end{array}$ \\
\hline \multicolumn{2}{|l|}{ Active engagement } \\
\hline Top 10 sub-agencies & Mean score \\
\hline $\begin{array}{l}\text { Environment and Natural Resources Division } \\
\text { Lyndon B. Johnson Space Center } \\
\text { Strategic Human Resources Policy Division } \\
\text { Goddard Space Flight Center } \\
\text { Civil Division, Department of Justice } \\
\text { Office of Inspector General } \\
\text { George C. Marshall Space Flight Center } \\
\text { Executive Office US Attorneys and US Attorneys' Office } \\
\text { Tax Division, Department of Justice } \\
\text { Human Capital Leadership and Merit System Accountability Division }\end{array}$ & $\begin{array}{l}4.39 \\
4.32 \\
4.31 \\
4.30 \\
4.29 \\
4.26 \\
4.26 \\
4.26 \\
4.25 \\
4.25 \\
\end{array}$ \\
\hline Bottom 10 sub-agencies & Mean score \\
\hline $\begin{array}{l}\text { Bureau of Engraving and Printing } \\
\text { Forest Service } \\
\text { Immigration and Customs Enforcement } \\
\text { Transportation Security Administration } \\
\text { National Drug Intelligence Center } \\
\text { Customs and Border Protection } \\
\text { Office of the Solicitor } \\
\text { Federal Aviation Administration } \\
\text { Bureau of Prisons/Federal Prison System } \\
\text { US Mint }\end{array}$ & $\begin{array}{l}3.91 \\
3.91 \\
3.90 \\
3.90 \\
3.90 \\
3.89 \\
3.88 \\
3.87 \\
3.85 \\
3.75\end{array}$ \\
\hline
\end{tabular}


The aspect of table 4 that most draws attention is that five sub-agencies in the Department of Justice (Environment and Natural Resources Division, Civil Division, Executive Office US Attorneys and US Attorneys' Office, Tax Division, and Criminal Division) are in the top-10 list in independent thinking, four of which (all except the Criminal Division) are also in the top 10 in active engagement. Also, four sub-agencies of the National Aeronautics and Space Administration (NASA) - Lyndon B. Johnson Space Center, Goddard Space Flight Center, George C. Marshall Space Flight Center, and John C. Stennis Space Center-are in the top-10 list for independent thinking. Three of them (all except the John C. Stennis Space Center) are ranked in the top 10 in active engagement.

\section{Followership by Location}

Public employees working at headquarters show slightly higher followership scores than those in the field (see Table 5). If medians are compared in a box-plot graph (figure 5), the boxes that represent the middle 50 percent of the data sample are almost identical in size. This shows that the homogeneity within and between each group is very similar. However, the difference between medians of independent thinking seems to be larger than the mean differences. This also explains the skew of the distribution and the existence of outliers in data for headquarters-based employees. For instance, the median of active engagement in headquarters is very close to the lower boundary of the box, which represents the 25th percentile of the data, whereas the median of independent thinking in headquarters is skewed toward the upper boundary.

Table 5. Followership by Location

\begin{tabular}{l|r|r|r|r|r}
\hline Location & $\begin{array}{c}\text { Independent } \\
\text { thinking (mean) }\end{array}$ & $\begin{array}{c}\text { Active engagement } \\
\text { (mean) }\end{array}$ & $\mathrm{N}$ & Percent & $\begin{array}{c}\text { Cumulative } \\
\text { percent }\end{array}$ \\
\hline Headquarters & 3.69 & 4.11 & 82,926 & 39.69 & 39.69 \\
Field & 3.64 & $\begin{array}{r}4.07 \\
125,982\end{array}$ & 60.31 & 100.00 \\
& Average: 3.66 & Average: 4.09 & Total: 208,908 & Total: 100.00 & \\
\hline
\end{tabular}


Figure 5. Followership by Location

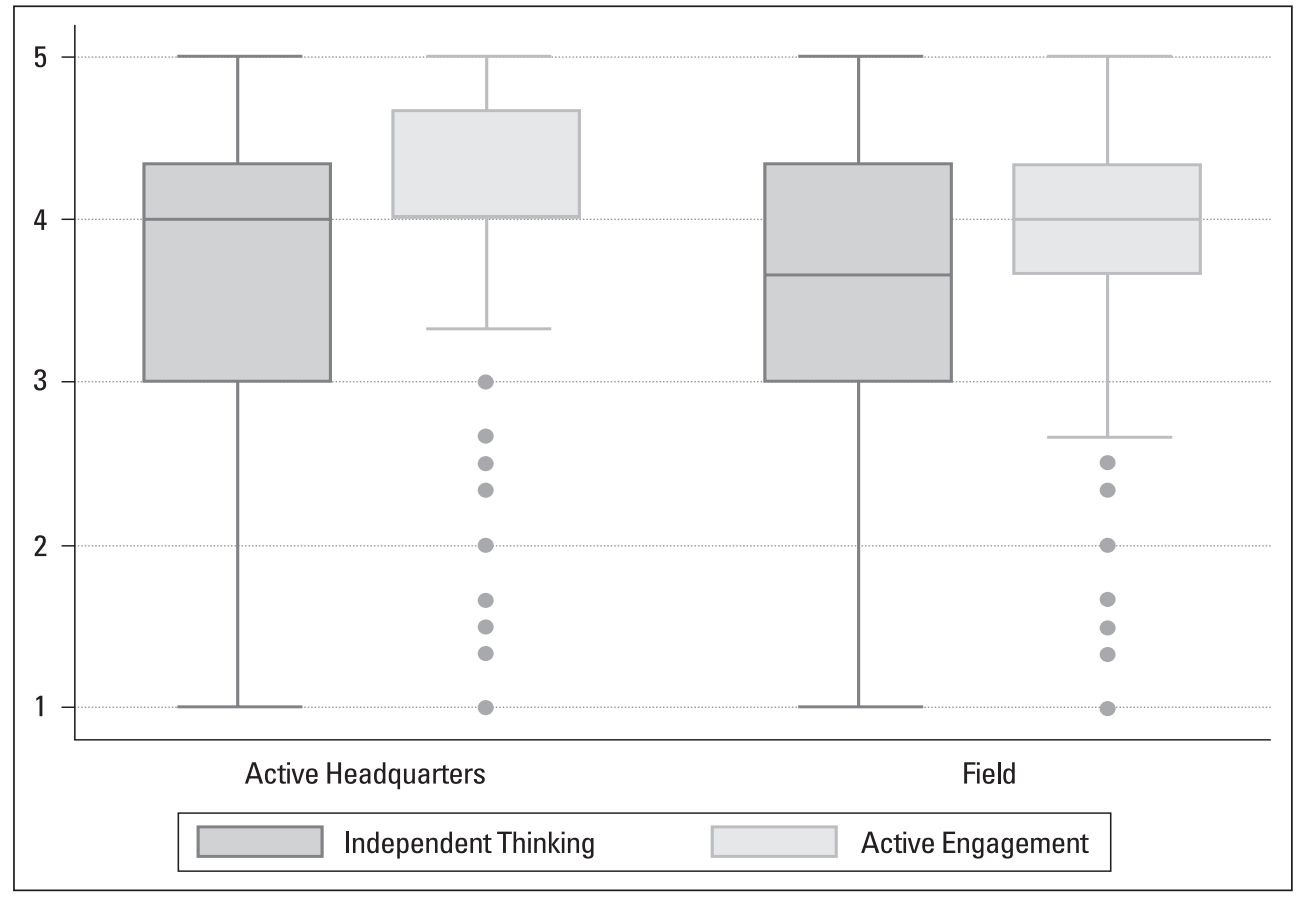

\section{Vertical Representation within Agencies}

This section explores followership differences within agencies based on supervisory status, pay category, age, experience in federal agency, and experience in current agency. Table 6 shows that the supervisory ranks are positively related to the levels of followership. Both independent thinking and active engagement consistently increase as rank increases. In the same vein, table 6 reveals the relationship between followership and pay category. The level of followership increases as the pay level increases.

Table 6. Followership by Supervisory Status

\begin{tabular}{l|c|c|r|r|r}
\hline Position & $\begin{array}{c}\text { Independent } \\
\text { thinking }\end{array}$ & $\begin{array}{c}\text { Active } \\
\text { engagement }\end{array}$ & $\mathrm{N}$ & Percent & $\begin{array}{c}\text { Cumulative } \\
\text { percent }\end{array}$ \\
\hline Non-supervisor & 3.52 & 4.01 & 116,266 & 55.66 & 55.66 \\
Team leader & 3.69 & 4.08 & 28,853 & 13.81 & 69.47 \\
Supervisor & 3.81 & 4.17 & 37,702 & 18.05 & 87.52 \\
Manager & 4.02 & 4.29 & 21,188 & 10.14 & 97.66 \\
Executive & 4.27 & 4.47 & 4,882 & 2.34 & 100.00 \\
Total & 3.66 & 4.09 & 208,891 & 100.00 & \\
\hline
\end{tabular}


Pay categories GS 13-15, SL, ST, and SES have higher followership than the overall average.

Age group does not have a noticeable impact on patterns in independent thinking, though the age group of 60 and older has the highest mean score. On the other hand, the mean score in active engagement consistently increases as employees gets older. In a similar line, though employees' work experience overall in the federal government and in their current agency do not increase or decrease as followership increases, the groups with more than 20 years tenure in the federal government and also in their current agency have high mean scores in both independent thinking and active engagement.

A relatively small percent of respondents answered the questions on tenure. Around 33 percent answered both questions; 140,787 (66.34 percent) did not answer on federal tenure, and 140,810 (66.35 percent) did not answer on agency tenure.

Followership does not show large differences between genders. Males have a higher mean score on independent thinking, while females have a slightly higher mean score in active engagement. Similar to the questions on tenure, 71,430 respondents (33.66 percent) answered and 140,793 (66.34 percent) did not answer the question on gender. Data weighting may adjust the possible biased estimates caused by the low response rate. Figure Tables 7-11 show followership scores by pay grade, age group, gender, and tenure in the federal government and in the employee's current agency.

Table 7. Followership by Pay Category

\begin{tabular}{l|c|c|r|r|r}
\hline Position & $\begin{array}{c}\text { Independent } \\
\text { thinking }\end{array}$ & $\begin{array}{c}\text { Active } \\
\text { engagement }\end{array}$ & N & Percent & $\begin{array}{c}\text { Cumulative } \\
\text { percent }\end{array}$ \\
\hline Federal wage system & 3.57 & 3.96 & 8,647 & 4.14 & 4.14 \\
GS 1-6 & 3.51 & 3.99 & 10,338 & 4.95 & 9.09 \\
GS 7-12 & 3.57 & 4.03 & 86,214 & 41.27 & 50.36 \\
GS 13-15 & 3.75 & 4.14 & 83,235 & 39.84 & 90.20 \\
Senior Executive & 4.31 & 4.49 & 3,931 & 1.88 & 92.08 \\
Service & & & & & \\
Senior Level (SL) or & 4.096 & 4.32 & 780 & 0.37 & 92.45 \\
Scientific or & 3.697 & 4.098 & 15,766 & 7.55 & 100.00 \\
Professional (ST) & 3.662 & 4.09 & 208,891 & 100.00 & \\
Other & &
\end{tabular}


Table 8. Followership by Age Group

\begin{tabular}{l|c|c|r|r|r}
\hline Age group & $\begin{array}{c}\text { Independent } \\
\text { thinking }\end{array}$ & $\begin{array}{c}\text { Active } \\
\text { engagement }\end{array}$ & $\mathrm{N}$ & Percent & $\begin{array}{c}\text { Cumulative } \\
\text { percent }\end{array}$ \\
\hline 29 and under & 3.67 & 4.04 & 8,858 & 4.24 & 4.24 \\
$30-39$ & 3.64 & 4.03 & 29,384 & 14.06 & 18.30 \\
$40-49$ & 3.66 & 4.08 & 64,119 & 30.69 & 48.99 \\
$50-59$ & 3.65 & 4.098 & 82,011 & 39.25 & 88.25 \\
60 or older & 3.73 & 4.15 & 24,557 & 11.75 & 100.00 \\
Total & 3.66 & 4.09 & 208,929 & 100.00 & \\
\hline
\end{tabular}

Table 9. Followership by Gender

\begin{tabular}{l|c|c|r|r|r}
\hline Gender & $\begin{array}{c}\text { Independent } \\
\text { thinking }\end{array}$ & $\begin{array}{c}\text { Active } \\
\text { engagement }\end{array}$ & $\mathrm{N}$ & Percent & $\begin{array}{c}\text { Cumulative } \\
\text { percent }\end{array}$ \\
\hline Male & 3.66 & 4.06 & 37,922 & 53.09 & 53.09 \\
Female & 3.59 & 4.08 & 33,508 & 46.91 & 100.00 \\
Total & 3.63 & 4.07 & 71,430 & 100.00 & \\
\hline
\end{tabular}

Table 10. Followership by Tenure in Federal Government Employment

\begin{tabular}{l|c|c|r|r|r}
\hline Tenure & $\begin{array}{c}\text { Independent } \\
\text { thinking }\end{array}$ & $\begin{array}{c}\text { Active } \\
\text { engagement }\end{array}$ & $\mathrm{N}$ & Percent & $\begin{array}{c}\text { Cumulative } \\
\text { percent }\end{array}$ \\
\hline Less than 1 year & 3.66 & 4.12 & 84 & 0.12 & 0.12 \\
1 to 3 years & 3.71 & 4.07 & 5,430 & 7.60 & 7.72 \\
4 to 5 years & 3.59 & 4.01 & 2,883 & 4.04 & 11.75 \\
6 to 10 years & 3.55 & 3.99 & 9,835 & 13.77 & 25.52 \\
11 to 14 years & 3.54 & 3.99 & 2,959 & 4.14 & 29.66 \\
15 to 20 years & 3.56 & 4.02 & 10,948 & 15.33 & 44.99 \\
More than 20 years & 3.67 & 4.10 & 39,297 & 55.01 & 100.00 \\
Total & 3.63 & 4.07 & 71,436 & 100.00 & \\
\hline
\end{tabular}

Federal tenure excludes military service.

Table 11. Followership by Tenure in Current Agency

\begin{tabular}{l|c|c|r|r|r}
\hline Tenure & $\begin{array}{c}\text { Independent } \\
\text { thinking }\end{array}$ & $\begin{array}{c}\text { Active } \\
\text { engagement }\end{array}$ & $\mathrm{N}$ & Percent & $\begin{array}{c}\text { Cumulative } \\
\text { percent }\end{array}$ \\
\hline Less than 1 year & 3.67 & 4.099 & 98 & 0.14 & 0.14 \\
1 to 3 years & 3.69 & 4.07 & 6,116 & 8.56 & 8.70 \\
4 to 5 years & 3.56 & 4.01 & 3,202 & 4.48 & 13.19 \\
6 to 10 years & 3.53 & 3.99 & 11,017 & 15.43 & 28.61 \\
11 to 20 years & 3.54 & 4.01 & 17,120 & 23.97 & 52.59 \\
More than 20 years & 3.70 & 4.12 & 33,860 & 47.41 & 100.00 \\
Total & 3.63 & 4.07 & 71,413 & 100.00 & \\
\hline
\end{tabular}




\section{DISCUSSION}

Followership characteristics in the US federal government were investigated within and between agencies. Among federal departments, the results showed the Department of State has the highest mean scores in both independent thinking and active engagement, while the Department of Transportation has the lowest scores. Since the descriptive statistics method does not control the variance of other variables, such as organizational characteristics or ethnicity, explaining the exact reason for the differences in followership mean scores is not easy. However, comparing the job characteristics based on the departments' mission statements can provide possible clues to the dissimilarities. The mission statement of the Department of State includes "helping to build and sustain a more democratic, secure, and prosperous world composed of well-governed states." Based on that mission statement, the job characteristics in the Department of State are very diverse and require creative performances at the international level. Therefore, it can be assumed that the work requires more than usual independent and critical thinking and proactive behavior.

On the other hand, the mission statement of the Department of Transportation states, "serve the United States by ensuring a fast, safe, efficient, accessible and convenient transportation system." The mission statement indicates employees in the Department of Transportation need to focus on updating and maintaining the overall transportation system. Compared to the Department of State, the job requires less proactive and more "by the book" behavior. This seems to be the case for the Department of Homeland Security as well. Its mission statement, "to lead the unified national effort to secure the country and preserve our freedoms and to prepare for and respond to all hazards and disasters," also asks employees to be promptly responsive to negative situations. Considering military-related agencies have high scores in both measures, the possible difference can be that Homeland Security may be more reactive, where military agencies are proactive.

Beside the agency's mission and the related nature of the organization's work, other agency factors such as management practices, culture, and organizational stability may influence federal employees' behavior (US MSPB, 2008). For instance, the mean score of the Department of Homeland Security on perceived procedural justice and supportiveness in the organization was second lowest, followed by the Department of Housing and Urban Development. A culture of less fairness and support could lead to lower followership. Interestingly, three federal departments that scored low in independent thinking have marginally lower proportions of employees in professional occupations than any other departments. However, these factors did not explain agencies with high scores in followership, which requires further analysis, such as multiple 
regression.

Another interesting finding is that none of the 15 federal departments are ranked in the top 10 on both measures. One reason for this can be the size of federal departments. Since the departments are larger than other federal agencies, there might be relatively more employees who are not working directly toward the agency's mission. For instance, five sub-agencies in the Department of Justice are ranked in the top-10 critical thinking list, but the mean score of the Department of Justice is not as high as those of its sub-agencies.

Agencies besides the federal departments that showed high mean scores in independent thinking are concentrating on tasks that require highly professional knowledge, including natural science, management, law, and trade. Accordingly, looking at the sub-agencies, five sub-agencies in the Department of Justice and four sub-agencies at the National Aeronautics and Space Administration are ranked in the top 10 for critical thinking; thus, the top nine sub-agencies are in two agencies. Seven sub-agencies in these two agencies also ranked in the top 10 for active engagement. Again, clues can be found from the mission statements of the two agencies that the agencies are pursuing goals that need creativity, not routine, and active (not reactive) engagement.

Regarding individual variation by different demographic factors, figure 6 illustrates the different followership styles of employees in different managerial positions. It is interesting to see that employees in executive positions have more exemplary and fewer alienated followers than those in other managerial positions. It can be inferred from the result that those who think critically and also actively engage are more likely to be selected for managerial positions. Other demographic factors do not distinctively explain the differences in followership, which may require further studies.

Figure 6. Followership Based on Managerial Level

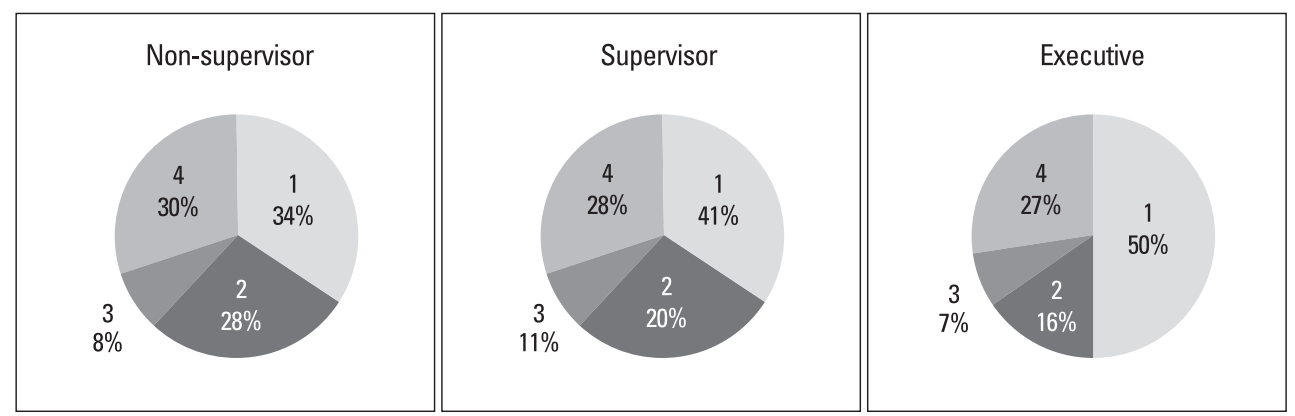

1 = exemplary; 2 = alienated; 3 = conformist; 4 = passive 
This study is meaningful in that it explores the degree of followership in different US federal agencies. Given that public organizations deal with complex issues, this study provides the common ground that different followership styles exist in public organizations. In other words, not only are different leadership styles required, but different followership styles needs to be anticipated and taken into account in public organizations.

\section{REFERENCES}

Bjugstad, K., Thach, E. C., Thompson, K. J., \& Morris, A. 2006. A fresh look at followership: A model for matching followership and leadership styles. Journal of Behavioral and Applied Management, 7(3): 304-319.

Carsten, M. K., Uhl-Bien, M., West, B. J., Patera, J. L., \& McGregor, R. 2010. Exploring social construction of followership: A qualitative study. The Leadership Quarterly, 21: $543-562$.

Chaleff, I. 1995. The courageous follower. San Francisco, CA: Berrett-Koehler Publishers.

2008. Creating new way of following. In R. E. Riggio, I. Chaleff, \& J. Lipman-Blumen (eds.), The art of followership: How great followers create great leaders and organizations. San Francisco, CA: Jossey-Bass.

Chrislip, D. D. 2002. The collaborative leadership fieldbook: A guide for citizens and civic leaders. San Francisco, CA: Jossey-Bass.

Dixon, G., \& Westbrook, J. 2003. Followers revealed. Engineering Management Journal, 15(1): 19-25.

Gilbert, G. R., \& Hyde, A. C. 1988. Followership and the federal worker. Public Administration Review, 48(6): 962-968.

Goffee, R., \& Jones, G. 2006. The art of followership. European Business Forum, 25: 22-26.

Greiner, L. E. 1972. Evolution and revolution as organizations grow. Harvard Business Review, Jul-Aug 50(4): 37-46.

Heifetz, R. A. 1994. Leadership without easy answers. Cambridge, MA: Harvard University Press.

Kellerman, B. 2007. What every leader needs to know about followers. Harvard Business Review, 85(12): 84-91.

Kelley, R. E. 1988. In praise of followers. Harvard Business Review, 66(6): 142-148. . 1992. The power of followership: How to create leaders people want to follow and followers who lead themselves. New York: Doubleday Currency. 
Lord, Robert G. (2008). Followers' Cognitive and Affective Structures and Leadership Process. In: R. E. Riggio, I. Chaleff, \& J. Lipman-Blumen (eds.), The Art of Followership: How Great Followers Create Great Leaders and Organizations. San Francisco, CA: Jossey-Bass.

Marion, R., and Uhl-Bien, M. (2001). Leadership in Complex Organizations. Leadership Quarterly, 12(4): 389-419.

Rost, J. 2008. Followership: An outmoded concept. In R. E. Riggio, I. Chaleff, \& J. Lipman-Blumen (eds.), The art of followership: How great followers create great leaders and organizations. San Francisco, CA: Jossey-Bass.

Tanoff, G. F., \& Barlow, C. B. 2002. Leadership and followership: Same animal, different spots? Consulting Psychology Journal: Practice and Research, 54(3): 157-165.

Townsend, P. (1999). Fitting teamwork into the grand scheme of things. Journal for Quality and Participation, 25(1): 16-18.

US MSPB (US Merit Systems Protection Board). 2008. Improving agency outcomes: The power of federal employee engagement. Washington, DC: author.

US OPM (US Office of Personnel Management). 2008. Federal human capital survey. Washington, DC: author.

Vigoda, E. 2002. From responsiveness to collaboration: Governance, citizens, and the next generation of public administration. Public Administration Review, 62(5): 527-540.

Yukl, G. 2009. Leadership in organizations (7th ed.). Englewood Cliffs, NJ: Prentice Hall.

Zaleznik, A. 1965. The dynamics of subordinacy. Harvard Business Review, May-Jun 43(3): 119-131. 